\title{
Regulatory Authority Jurisdiction Territory Code
}

National Cancer Institute

\section{Source}

National Cancer Institute. Regulatory Authority Jurisdiction Territory Code. NCI

Thesaurus. Code C94056.

A coded value specifying the geographical area or limits an authority has to make laws and enforce them. 